\title{
The Grootfontein aquifer: Governance of a hydro- social system at Nash equilibrium
}

\author{
AUTHORS: \\ Jude E. Cobbing ${ }^{1}$ \\ Maarten de Wit ${ }^{1}$

\section{AFFILIATION: \\ ${ }^{1}$ AEON/ESSRI, Nelson Mandela \\ University, Port Elizabeth, \\ South Africa}

\section{CORRESPONDENCE TO: Jude Cobbing}

EMAIL:

jcobbing@gmail.com

\section{DATES:}

Received: 05 Aug. 2017

Revised: 26 Sep. 2017

Accepted: 04 Jan. 2018

Published: 30 May 2018

\section{KEYWORDS:}

groundwater; management; institutions; transdisciplinarity; resilience

\section{HOW TO CITE:}

Cobbing JE, De Wit M. The Grootfontein aquifer: Governance of a hydro-social system at Nash equilibrium. S Afr J Sci. 2018;114(5/6), Art. \#2017-0230, 7 pages. http://dx.doi.org/10.17159/ sajs.2018/20170230

\section{ARTICLE INCLUDES: \\ $\times$ Supplementary material \\ $\times$ Data set}

\section{FUNDING:}

Water Research Commission (South Africa)

(C) 2018. The Author(s). Published under a Creative Commons Attribution Licence.
The Grootfontein groundwater aquifer is important to the water supply of the town Mahikeng in the North West Province of South Africa and to commercial agriculture in the Province, but the water table has fallen by up to $28 \mathrm{~m}$ as a consequence of over-abstraction since the 1980s. Institutional and hydrogeological issues impact the aquifer in complex ways, described here as a hydro-social system. Whilst the hydrogeology is well understood and South African laws provide for sustainable groundwater governance, poor stakeholder collaboration and other institutional problems mean that the overabstraction is likely to persist - an example of an undesirable Nash equilibrium. The Grootfontein aquifer case shows that groundwater underpins wider social-ecological-economic systems, and that more holistic management - taking the institutional context into account - is needed to underpin economic growth, employment and other public outcomes.

\section{Significance:}

- The cost of better natural resource stewardship, including groundwater, is likely to be considerably less than the losses that occur when it is absent.

- If local groundwater was better managed, it could make water supplies in Mahikeng cheaper and more reliable, which would in turn support local economic growth and employment.

\section{Introduction}

Groundwater's global social, economic and environmental importance contrasts with its low profile amongst policymakers and the general public. It is the primary domestic water source for about half of the global population', and for about three quarters of Africa's population². More than half of all South Africans depend on groundwater for their domestic water supply ${ }^{3}$, and the total renewable volume of groundwater in South Africa is similar to the surface water assured yield ${ }^{4,5}$. Groundwater cannot deliver large volumes at a single location like a dam, but its dispersed nature is an advantage in supplying rural areas and scattered small settlements with potable water. Whilst South Africa's surface water resources are nearly fully allocated, only around half of the national renewable groundwater resource is used. ${ }^{5,6}$

Unfortunately, groundwater supply systems in South Africa are often poorly maintained ${ }^{7}$, and groundwater management is inadequate ${ }^{8,9}$. Municipalities tend to prefer surface water over groundwater. ${ }^{7}$ Here we examine a well-studied and prolific South African aquifer - the Grootfontein dolomite aquifer in the North West Province - to investigate poor groundwater management and to discern wider lessons for social-ecological-economic stewardship in South Africa.

The North West dolomites, which stretch from Gauteng Province to the border with Botswana, are amongst South Africa's most important and prolific groundwater aquifers. ${ }^{10,11}$ They cover an area of about $5000 \mathrm{~km}^{2}$, hold a renewable water resource of similar magnitude to the Gariep Dam, and receive natural recharge of about $300 \mathrm{Mm}^{3} / \mathrm{a}^{12,13}$ This groundwater resource supports extensive agricultural irrigation and the water supplies of towns such as Itsoseng, Lichtenburg, Mahikeng, Ottoshoop, Ventersdorp and Zeerust, as well as hundreds of dispersed settlements and homesteads. The North West dolomites are sub-divided into a patchwork of semiautonomous units or 'compartments' by geological features such as igneous dykes..$^{12,14}$ Under natural conditions, each compartment discharges groundwater via springs and wetlands, and is recharged by rainfall. One of these compartments is the Grootfontein compartment or aquifer, for which inadequate groundwater management has contributed to falling water levels.

The Grootfontein aquifer, which is $30 \mathrm{~km}$ southeast of the town of Mahikeng, was Mahikeng's main water source until the early 1980s. Today it supplies only about $20 \%$ of the town's water (about $10 \mathrm{ML} /$ day) because its yield has declined and Mahikeng's demand has grown. ${ }^{15}$ The rest of Mahikeng's water comes from a large spring, the Molopo Eye, which drains a different dolomite compartment to the north of the Grootfontein aquifer (about $20 \mathrm{ML} /$ day), and the Setumo Dam on the ephemeral Molopo River, downstream of Mahikeng (another $20 \mathrm{ML} /$ day); see Figure 1.

\section{Problem statement}

The Grootfontein aquifer once discharged naturally at its northern (down-gradient) boundary, mainly from a large spring (the 'Grootfontein', or great spring). The drilling of boreholes around the spring to increase Mahikeng's supply in the 1970s, combined with large increases in irrigation abstractions elsewhere in the compartment, finally dried up the spring in 1981. As water levels in the aquifer dropped further, some of the boreholes around the spring failed. Today the groundwater level in the Grootfontein aquifer near the former spring is more than $28 \mathrm{~m}$ below ground level. ${ }^{15}$ The three remaining viable public water supply boreholes at the former spring now yield less than half of the original combined wellfield potential (i.e. only about $10 \mathrm{ML} /$ day). Irrigating farmers, who abstract the lion's share of the groundwater, are concerned about falling water levels, higher pumping costs and growing uncertainty. 


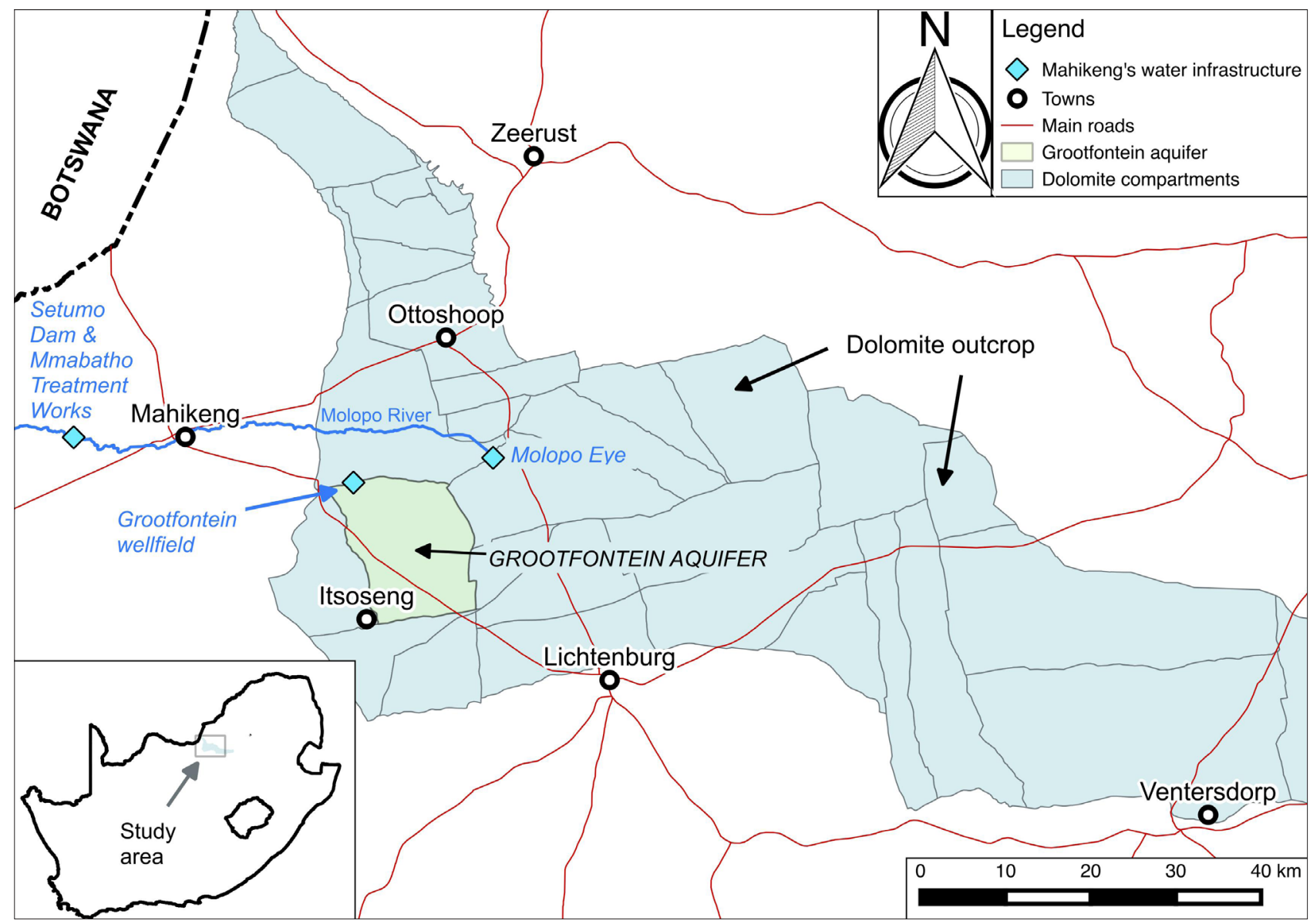

Figure 1: The Grootfontein aquifer and the dolomite outcrop near Mahikeng (boundaries after Holland and Wiegmans ${ }^{14}$ ).

Partly in response to the uncertain supply from Grootfontein, Mahikeng city officials have invested more than ZAR30 million in upgrading the water treatment plant at the Setumo Dam, from a supply of $10 \mathrm{ML} /$ day to today's $20 \mathrm{ML} /$ day. ${ }^{16}$ The Setumo Dam receives a large proportion of its inflow from discharges from Mahikeng's two wastewater treatment plants, and from leaks in the town's reticulation system. The dam water quality is consequently poor, requiring sophisticated treatment to attain South African drinking water quality standards. ${ }^{16}$ In contrast, Mahikeng's groundwater sources are of generally good quality, needing only prophylactic chlorination before entering supply. As the dam depends partly on return flows from the town, and the Molopo Eye spring is vulnerable to small changes in water level, the Grootfontein aquifer is more important than it might appear.

Hydrogeologically, the Grootfontein aquifer is amongst the best-studied aquifers in South Africa ${ }^{17}$, with technical research dating back to the 1960 s or before ${ }^{18,19}$. At least 15 of the South African Department of Water and Sanitation (DWS)'s technical geohydrology reports concentrate on Grootfontein. ${ }^{17}$ Some hydrogeological uncertainty remains, but in general Grootfontein is technically well understood. ${ }^{15}$

Groundwater levels at Grootfontein have been falling since the early 1980s, despite the relatively thorough hydrogeological understanding of the aquifer, ${ }^{15,17,20}$ its proximity and importance to a provincial capital, and the legal mechanisms intended to prevent overuse. Figure 2 summarises the records of 21 DWS groundwater-level monitoring stations within the Grootfontein aquifer. Blue columns show the difference between the mean of the first year's readings and the mean of the last year's readings for each record (about $0.44 \mathrm{~m} / \mathrm{a}$ on average), and red columns show average decline based on a straight-line fit through each record (about $0.46 \mathrm{~m} / \mathrm{a}$ on average). ${ }^{15,17}$ Station record lengths vary between 16 and 43 years. Higher average declines occur near the Grootfontein wellfield. ${ }^{17}$ This overall decline has caused the failure of some boreholes abstracting water for Mahikeng, has increased costs and uncertainty for irrigating farmers, and has deprived Mahikeng of the reserve of groundwater that a higher saturated aquifer thickness would allow.

Sound technical knowledge of the aquifer, and legal provisions designed to prevent over-exploitation, plainly do not ensure sustainable use of Grootfontein groundwater. The question therefore arises: What is necessary for the successful management of the Grootfontein aquifer?

\section{Methodology}

Research carried out between 2013 and 2015 aimed to understand the reasons for poor groundwater governance at Grootfontein. The existing extensive hydrogeological knowledge of Grootfontein implies that social and institutional dynamics underpin poor governance, rather than lack of technical knowledge. However, we also investigated the current hydrogeological understanding of the aquifer, because this understanding delineates physical limits to management interventions. A mixed-methods research approach was therefore used ${ }^{21}$, which combined social science and physical science techniques, in keeping with the principles of earth stewardship science ${ }^{22}$.

This research approach combined conventional hydrogeological methods (literature review, field sampling, and analysis of hydraulic parameters leading to a conceptual model and water balance), with 63 field interviews and participant observation. ${ }^{17}$ Participant observation means taking part in meetings as a recognised participant, for example a meeting called by DWS to discuss the aquifer, or a municipal water infrastructure tender briefing. This participation helped illuminate the day-to-day working environments of the main organisations involved in groundwater governance at Grootfontein, and the formal and informal interactions between these organisations. A combination of quantitative evidence (e.g. water levels, pumping volumes, chemical analyses) and qualitative evidence (e.g. interview responses, or the absence of a groundwater protection zone around a borehole) was used to corroborate conclusions in a process of triangulation. ${ }^{21}$ 


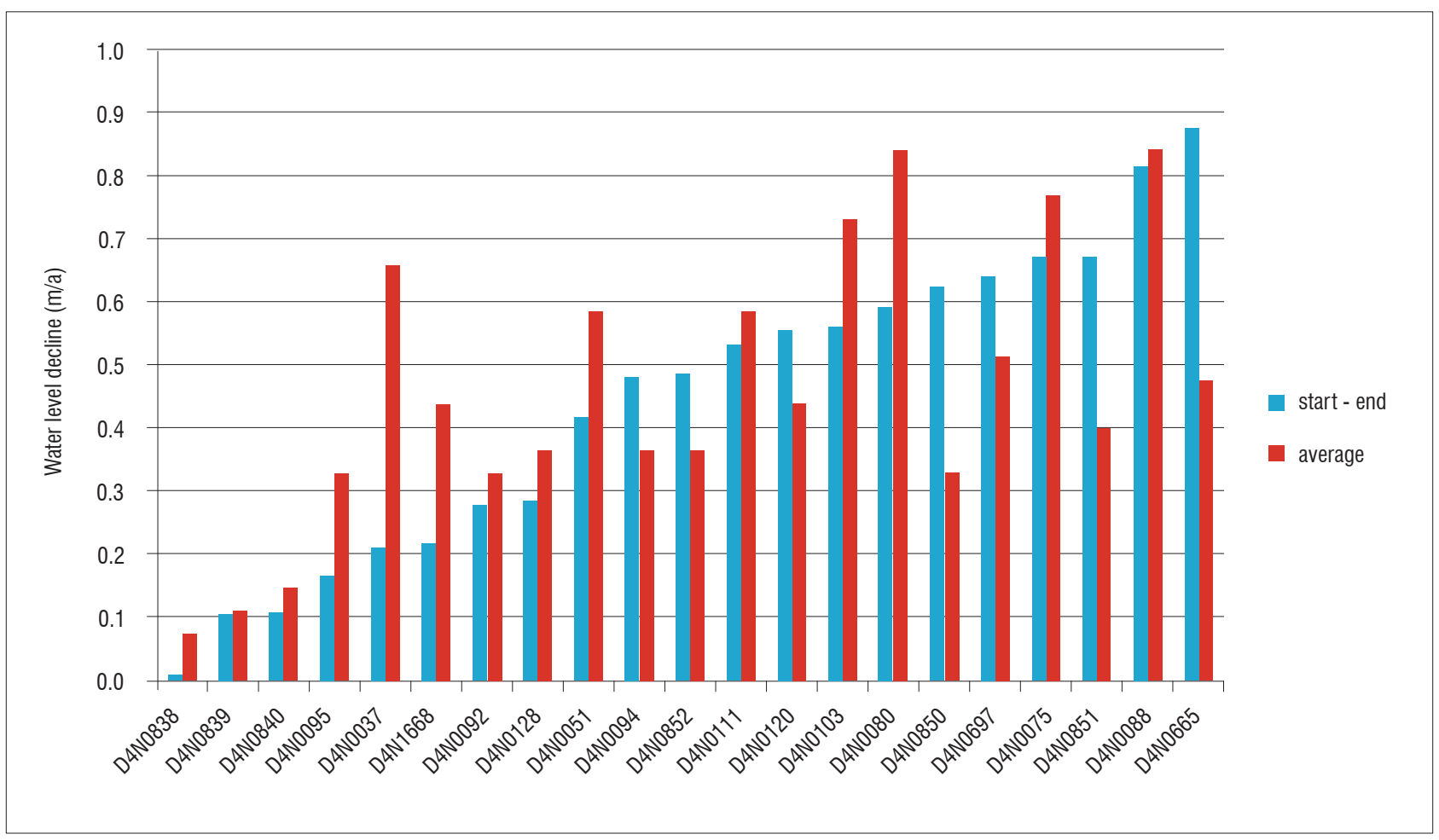

Data source: South African Department of Water and Sanitation

Figure 2: Rates of water level decline for the Grootfontein aquifer.

It became clear that both the social/institutional and the hydrogeological/ technical aspects of the aquifer's functioning were important to any attempt to address the complexity of this resource. Indeed, the situation at Grootfontein can be characterised as a 'hydro-social system', meaning that these aspects influence each other in relatively complex and often counter- and non-intuitive ways.

Whilst the social and institutional aspects appear to control the eventual outcomes regarding water use and water levels, the hydrogeology defines what is physically possible. Aspects of the hydrogeology also heavily influence the institutional features of the system. For example, the heterogeneity of hydraulic properties as a function of complex weathering and karst formation reinforces a common notion of the dolomite groundwater resource as mysterious and unreliable. We argue that knowledge of both the institutional and the hydrogeological aspects is necessary in order to understand the hydro-social system. No hierarchy is implied.

\section{Results}

\section{Overview of the governance of the Grootfontein aquifer}

Sweeping changes to South African water law since 1997 mean that ownership of water is now vested in the state via the Department of Water and Sanitation (DWS). The law specifies minimum volumes of water for environmental functioning and for basic human needs, which take precedent over other uses..$^{23} \mathrm{All}$ other water uses must be licensed. In practice, verification of licenced quantities (e.g. of irrigation boreholes) is rare, and penalties for over-abstraction are uncommon. The principle of subsidiarity or decentralisation is prescribed ${ }^{24}$, but most of the envisaged basin-level and local-level organisations have not emerged since the new legislation, which is now being revised ${ }^{25}$.

In particular, the National Water Act ${ }^{23}$ envisages Water User Associations (WUAs) as cooperative local associations of individual water users that manage water along integrated water resource management lines. WUAs were intended to replace the apartheid-era irrigation boards, emphasising equitable access to water and improving social outcomes. Constitution of the WUAs was very slow, with DWS concerned that proposed WUAs merely replicated former structures. No WUAs were ever approved for the aquifers of the North West dolomites, and today DWS no longer supports WUAs and is disbanding those that do exist elsewhere in the country. ${ }^{25}$

Major stakeholders at Grootfontein with a direct influence on the groundwater abstractions include DWS, the irrigating farmers, the local and district municipalities, and the regional water board. Technical and policy advisors and consultants, and other government departments, also have a role. As described, semi-structured interviews and participant observation methods were used to gain insight into these stakeholders, ${ }^{17}$ which are briefly summarised here:

1. The two municipalities (Mahikeng Local Municipality and Ngaka Modiri Molema District Municipality, or NMMDM) are challenged by issues including internal organisation, budgeting, mandate and skills, and consequently struggle to fulfil their mandates. In 2014, NMMDM was placed under provincial administration. ${ }^{26}$

2. The regional water board, Sedibeng Water Board, has considerable technical resources and has received unqualified audits since $2002 .{ }^{27}$ It took over the underperforming Botshelo Water Board in early 2015. Sedibeng Water Board's responsibilities in Mahikeng include the two water treatment plants, the Setumo Dam, both wastewater treatment plants, and a portfolio of water reticulation, storage and metering assets. It also has responsibility for large rural areas with many small groundwater sources. It is focusing on the upgrade to the Mmabatho Water Treatment Works; management of the primary groundwater sources (the Grootfontein wellfield and the Molopo Eye) is carried out by DWS.

3. DWS, as the legal custodian of all water in South Africa, has ultimate responsibility for water resources such as Grootfontein, where it operates and manages the wellfield. It has an office in Mahikeng, and a small satellite office at the Grootfontein wellfield. In 2015, DWS was working on the proposed nine Catchment Management Agencies, with final responsibilities for licensing and control of local groundwater resources still to be resolved. DWS opposes WUAs because they are thought to replicate undesirable past modes of governance, but this policy has unintentionally contributed to the lack 
of effective local-level groundwater management organisations. ${ }^{17}$ The emerging Catchment Management Agencies will eventually assume the WUA responsibilities, but in the meantime these functions are partly vested in Catchment Management Forums and Stakeholder Operating Forums hosted and organised by DWS. In general, these interim forums do not attract wide stakeholder support in Mahikeng, and are convened by relatively junior DWS personnel. ${ }^{17}$ Issues of internal organisation and mandate also challenge DWS,$^{28}$ which in turn contributes to poor availability of internal hydrogeological data, inadequate protection measures at the Grootfontein wellfield, and poor verification and validation of groundwater abstraction licences.

4. Irrigating farmers at Grootfontein abstract most of the groundwater, mainly to feed centre-pivot irrigation systems.${ }^{17}$ No effective forum exists to manage these groundwater abstractions, and irrigation abstractions are limited primarily by infrastructure characteristics, electricity prices and irrigation requirements. Farmers are not as homogeneous a group as is sometimes assumed, and farm incomes depend on groundwater irrigation to varying degrees. In some cases, irrigation could be substantially reduced with proportionately little impact on farm income, such as by changing crop types or by allowing fields to lie fallow in the dry winter months.

5. Other stakeholder groups at Grootfontein include technical consultants, international policy experts and other government departments (e.g. National Treasury) which, although they have little direct stake in Grootfontein groundwater, have significant long-term influence on groundwater policy and operations. On the other hand, numerous local households and small businesses (e.g. at Itsoseng) depend on Grootfontein groundwater; these users abstract small amounts that are critical to livelihoods, but have little influence on abstraction policy.

\section{Analysis of governance at Grootfontein}

Irrigating farmers at Grootfontein are reluctant to unilaterally reduce abstractions, without a similar gesture from DWS or from NMMDM as the water services provider. DWS and NMMDM consider some farmers to be in breach of abstraction licence agreements, but are reluctant to engage in legal or other actions to address this breach - a situation that is complicated by ongoing organisational changes at DWS, technical difficulties in assessing abstraction volumes, and poor relations between DWS and NMMDM. ${ }^{17}$ No effective local forum exists in which 'win-win' situations are debated - a situation exacerbated by the demise of WUAs in the North West dolomites and the inadequate interim replacements.

Misperceptions about the aquifer potential are worsened by a lack of accessible abstraction and other hydrogeological data, although these data do exist. Institutional bias towards surface water inclines many stakeholders (including DWS) towards upgrading the Mmabatho Water Treatment Works at the Setumo Dam $^{16}$, and even a pipeline from another catchment ${ }^{17}$. These surface water solutions also allow city officials to avoid tackling groundwater governance problems.

An analysis of the various stakeholders at Grootfontein was carried out, using the six institutional characteristics or 'appropriator attributes' suggested by 0 strom ${ }^{29}$ as a framework ${ }^{17}$. These six appropriator attributes are 29 .

1. Salience: Appropriators depend on the resource system for a major portion of their livelihood or the achievement of important social or religious values.

2. Common understanding: Appropriators have a shared image of how the resource system operates and how their actions affect each other and the resource system.

3. Low discount rate: Appropriators use a sufficiently low discount rate in relation to future benefits to be achieved from the resource.

4. Trust and reciprocity: Appropriators trust one another to keep promises and relate to one another with reciprocity.
5. Autonomy: Appropriators are able to determine access and harvesting rules without external authorities countermanding them.

6. Prior organisational experience and local leadership: Appropriators have learned at least minimal skills of organisation and leadership through participation in other local associations or through learning from approaches that neighbouring groups have taken.

If present in a group of common pool resource appropriators, these appropriator attributes '...enhance the likelihood of appropriators organising themselves to try to avoid the social losses associated with open access or rules that are not yet working well'29. It was found that the hydro-social system at Grootfontein does not possess any of these appropriator attributes, making it less likely that stakeholders would naturally organise themselves or collaborate to manage the aquifer sustainably. ${ }^{17}$ These appropriator attributes depend not only on the current characteristics of the appropriators (or stakeholders), but also on the history of interactions between them and various other factors. According to 0strom, attributes are '... affected by the larger regime in which a resource and its appropriators are embedded'29.

The current situation can be described as a sub-optimal equilibrium or stalemate, in which major abstracting stakeholders have no incentive to reduce abstractions. ${ }^{17}$ Instead, stakeholders maximise abstractions whilst the resource lasts - a classic 'tragedy of the commons'30. Suboptimal equilibria of this sort are sometimes known as Nash equilibria - a term originating in mathematical game theory and referring to situations in which 'players' perceive no advantage to changing their behaviour, despite a collective long-term sub-optimal outcome. ${ }^{31,32}$ As Nasar ${ }^{31}$ puts it:

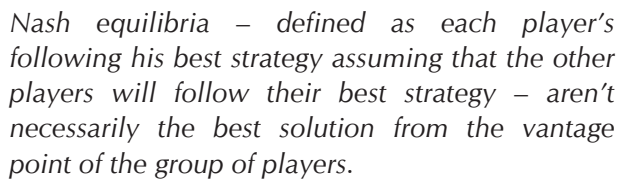

In order to break a Nash equilibrium and precipitate change, one 'player' or stakeholder needs to 'make a move' that may be disadvantageous in the short term.

An effective local forum needs to intervene, and be backed by good data availability and with powers of coercion and (if necessary) enforcement. WUAs were originally conceived as such, but were never constituted. Of the major stakeholders, DWS has the best chance of convening, forming or otherwise presiding over such a forum..$^{33}$ DWS is legally mandated to assume such a role, whereas other stakeholders are unlikely to intervene unilaterally. Irrigating farmers, the major users of Grootfontein groundwater, see eventual failure of the resource as possible, but have neither the internal organisational attributes nor external incentives to change their behaviour.

The slow change from DWS regional offices to Catchment Management Agencies, the perception that the issues are being addressed by the Stakeholder Operating and Catchment Management Forums, internal organisational difficulties (e.g. in accessing data) and a lack of support from senior management mean that DWS is unlikely to make significant changes to the situation in the near future. The apportionment of blame for the situation, linked to the false promise of 'hard-state' authoritarian legal remedies ${ }^{34}$, feeds a zero-sum mentality and detracts from the complex and incremental task at hand ${ }^{17}$. Thus over-abstraction at Grootfontein is likely to continue.

The analysis described above has implications for hydrogeological research in South Africa, and also for the wider social, environmental and economic context. These implications are discussed in the next section.

\section{Implications of the findings}

\section{Implications for hydrogeological research}

The Grootfontein aquifer is well understood technically, and could provide a larger and more reliable supply of good quality water to Mahikeng. ${ }^{15}$ Analysis of the complex web of organisations and stakeholders outlined 
above suggests that the crux of the over-abstraction problem lies not in poor technical knowledge, but is in fact a more complex social and institutional issue. The problem is nevertheless often wrongly framed, explicitly or implicitly, as related to a lack of data or to the vagaries of a fundamentally capricious and unreliable aquifer. Calls for better understanding of the recharge, or more explicit delineation of the aquifer boundaries, inadvertently reinforce this misperception and detract from the central issue, which is that governance arrangements are inadequate.

The interdependence of the hydrogeology and the institutional framework for governance means that groundwater governance at Grootfontein (and elsewhere) can be described as a political economy issue. Political economy analysis examines institutional interactions and functioning in the context of how power is apportioned and finds traction. ${ }^{35}$ The technical (or hydrogeological) characteristics are only one component of the political economy of a groundwater supply system, but political economy issues are often ignored by technical specialists.

However, classic political economy analysis can place too little emphasis on the technical hydrogeology. At worst it tends to assume that water governance can be understood by examining only the institutional, economic and material circumstances of the participants, with the influence and feedback of the hydrological sphere relegated to the margins. It is convenient to see all water resources as essentially similar. The institutional or social sphere must in fact evolve alongside the physical characteristics of the hydrological system, or risk collapse when underlying hydrological assumptions prove false.

Hydrogeological characteristics provide a boundary of hydraulic possibility, but other factors control who abstracts how much groundwater, and when. This implies that any final 'safe yield' figure at Grootfontein (as elsewhere) will essentially be politically mediated the ideal hydraulic figure may differ from the best figure in the wider institutional sense, particularly when multi-year aquifer changes are under consideration, and refinements to hydraulic figures are in any case consequent on feedback from 'adaptive management' arrangements. .,36 $^{9,36}$

Most hydrogeological research at Grootfontein has been state funded, which implies a fundamental public interest. If hydrogeological research cannot be explicitly linked to public interest outcomes, then justifying and funding such research will become increasingly difficult. This in turn implies that hydrogeologists (and other technical specialists) should understand and even explicitly account for the political economy or institutional context of their work. Ignoring this context may damage the link between scientific research and public policy, or worse, erode the social licence to operate as publicly mandated researchers.

\section{Implications for the environment and the economy}

As Grootfontein illustrates, important groundwater supplies in South Africa have inadequate governance systems that enable over-abstraction. Inadequate groundwater governance in turn harms economic growth, food security, social stability, land reform, transformation and other sectors.

Parts of Mahikeng are supplied with diluted wastewater, which is treated to obtain drinking water standards at the multimillion rand Mmabatho Water Treatment Works. At the same time, groundwater of excellent quality is being used to irrigate crops, including maize destined for cattle feed. Apart from the higher cost of treating wastewater, Mahikeng is dependent on a high-tech treatment plant that has failed in the past ${ }^{16}$ and may fail again. This situation also lowers the resilience of Mahikeng's water supply system as a whole by increasing its vulnerability to unexpected shocks or outages. Mmabatho Water Treatment Works is technically sophisticated and well engineered, but all such systems depend on long institutional chains involving funding, staffing, consumables supply, maintenance and financing. Utilising the superior water quality and storage of the Grootfontein and other dolomite compartments would increase overall system resilience by incorporating passive systems requiring lower energy and capital inputs, such as back-up storage underground. The resilience of the town's water supply system in turn impacts on the perceptions of residents, investors and businesses, and on the wider resilience of its economic and social functioning.
Environmental impacts of groundwater over-abstraction in the North West dolomites include the destruction of several large springs and associated wetlands and ecosystems (e.g. the Grootfontein Eye, the Lichtenburg Eye and the Polfontein Eye at Itsoseng).

The Grootfontein hydro-social system is therefore a component of wider regional social-ecological-economic systems, each with a complex range of intermingled institutional characteristics as well as bounding technical or physical limits. Such systems are difficult to depict and characterise, and are inherently transdisciplinary. They are also dynamic in nature, and evolve in response to diverse forces. The discourse of 'resilience' is useful when considering this bigger picture.

\section{Implications for resilience}

Arising out of ecological studies and the sustainability discourse, resilience refers to the ability of a dynamic system to absorb shocks, as well as to the 'capacity for renewal, re-organisation and development' ${ }^{37}$. Human societies are ultimately dependent on their ecological context ${ }^{38}$, and the profit-driven externalising of environmental damage may be ultimately self-limiting on aggregate ${ }^{39}$. A resilient social-ecological-economic system is one that adapts to shocks (e.g. droughts, pollution, commodity price collapse) and persists, whilst minimising adverse consequences (e.g. a rise in unemployment, or long-term ecological damage).

The economy is also important to resilience - economic dynamism is a pre-requisite for the political and social stability required to overcome complex long-term environmental problems. In some cases, resilience (and linked fields such as sustainability science) can put the cart before the horse, thereby reflecting a myth more common in the developed world that economic progress requires parallel environmental sustainability. Historically, economic development is more closely correlated with environmental devastation, at least in the short and medium term. Today, many economists believe that economic development can and should be delinked from unsustainable environmental exploitation, and there is an ethical case for this belief. Environmental devastation is also possible without catalysing economic development - an outcome unfortunately common across Africa.

Social-ecological-economic systems that are poorly understood, or are simplistically outlined based on convenient or politically expedient variables, are more vulnerable to unexpected 'cascades of failure' that can occur in complex systems in which linkages and feedback mechanisms are ill defined. ${ }^{40,41} \mathrm{~A}$ limited understanding of such systems reduces resilience as effectively as concrete factors such as drought or lack of finance, as it prevents optimal resource allocation and increases risk.

The problem is not unique to Grootfontein. We briefly describe two further examples that illustrate the linkages between poor groundwater governance in the North West dolomites and the wider social-ecologicaleconomic context:

1. Over-abstraction of groundwater from the dolomite aquifers in and around the town of Lichtenburg has been scientifically described since the $1960 \mathrm{~s},{ }^{42}$ but never resolved. It has contributed to domestic water shortages, burning of peat deposits, concerns over the viability of dairying, irrigated agriculture, cement production and other economic activities, and the drying up of the town spring (the Lichtenburg Eye) and associated public amenity. It also contributes to a corrosive sense that the designated authorities fail to act in the public interest more generally. In the short term, these things incentivise further over-abstraction, also seen at Grootfontein. Long term, they fuel lack of investment and unemployment.

2. Poor management of groundwater levels in the Steenkoppies dolomite compartment near Krugersdorp threatens the viability of valuable irrigated agriculture as well as businesses and ecosystems downstream that depend on Magalies River water. 43,44 It has led to de facto 'management by court order' in which potential partners in collaborative management shun each other, or threaten each other in court. The situation militates against the kind of economic dynamism, social cohesion and catalysing of opportunity necessary for the step-increase in the numbers of dignified, decently paid jobs 
envisaged by the National Development Plan. ${ }^{45}$ Recognising key linkages between groundwater and other sectors is a first step to improving governance, and ultimately promoting a more resilient social-ecological-economic system at Steenkoppies.

\section{Policy discussion}

A key factor in North West dolomites groundwater governance problems is the lack of true collaboration between local stakeholders and central authority. DWS's decision to withhold official recognition of WUAs in the North West dolomites unintentionally contributed to the breakdown of formal local groundwater governance mechanisms, the de facto continuation of past modes of water use and governance, and a general cynicism and short-termism. This decision is justified on the grounds that the incipient WUAs were socially regressive, but the lack of an authoritative, speedy and effective replacement has inadvertently worsened the problem. New policies must be put into practice. As Aarnoudse et al. ${ }^{46}$ put it:

New policies are not institutions as such. They first need to relate to existing patterns and structures and add to, synergise with or replace them in order to achieve institutional change.

Decentralised modes of governance imply theoretically lower transaction costs, better consultation and faster decisions, but a central authority is also needed to break logjams, and engage with, endorse and hold accountable local governance decisions in line with the democratic mandate. ${ }^{47} \mathrm{~A}$ central authority has a wider perspective of regional socialecological-economic systems, and can if necessary make decisions that increase overall resilience even when this might oppose parochial or short-term interests (e.g. in breaking local Nash equilibria). The National Water Act explicitly recognises this function of central government. ${ }^{23,24}$ DWS has not always played this role in the North West dolomites ${ }^{33}$; even the verification and validation of large volume groundwater abstraction licences - a first step in effective governance - has faltered.

Collaboration between government departments (e.g. DWS; the Department of Rural Development and Land Reform; the Department of Agriculture, Forestry and Fisheries; the Department of Economic Development; and the National Treasury) and across spheres of government (e.g. between municipalities, provincial government and national government) is inadequate when it comes to groundwater governance, despite this resource underpinning many explicit goals of the various sectors. Such collaboration is essential if optimal social outcomes are to be achieved. The general problem of poor crosssectoral coordination in South Africa has been recognised in the National Development Plan ${ }^{45}$, but is particularly acute in the field of groundwater governance because groundwater is hidden from view, both physically and institutionally. ${ }^{17}$

The costs of less-resilient or more vulnerable social-ecological-economic systems, whilst difficult to quantify, are much higher than the costs incurred by effective management. The risks of water supply failure, with unpredictable implications, are also disproportionately borne by the poor and the vulnerable. Wealthier individuals and businesses can insulate themselves against water supply uncertainty (e.g. by installing on-site storage or household reverse-osmosis treatment systems), but in the long run society prospers or fails together.

In the absence of effective policy and action, there is an implicit endorsement of the potentially regressive and short-term modes of environmental governance that arise ad hoc, and that often owe much to past laws or past forms of social and demographic interaction. A 'business as usual' approach, based either on the absence of policy or on the division of the social-ecological-economic sphere into silos, is unlikely to bring about the kind of step change in environmental governance (and socioeconomic development) that is required to break the Nash equilibrium.

\section{Conclusions}

Groundwater over-exploitation at Grootfontein is neither natural nor inevitable, but is the collective result of stakeholder actions and choices over many years. These actions are based not only on laws and formal water governance policies, but rely also on hierarchies of power, historical modes of thought and perception, short-term socio-political incentives, interference from other sectors (e.g. agriculture and land reform), and other institutional factors. These factors are less tangible and more controversial than the physical hydrogeology or water resource.

The Grootfontein hydro-social system responds to natural changes (e.g. droughts and recharge events) and to social or institutional pressures (e.g. over-pumping, availability of infrastructure funding, political priorities). Better management requires an understanding of both. The Grootfontein hydro-social system is in turn a component in wider socialecological-economic systems, whose resilience is important for national development and public outcomes.

\section{Acknowledgements}

We thank the Water Research Commission for funding part of this research, interviewees in Mahikeng and elsewhere, and hydrogeologists at the Department of Water and Sanitation.

\section{Authors' contributions}

J.E.C. was responsible for the conceptualisation, methodology, data collection, data analysis, sample analysis, data curation, writing the initial draft, writing revisions, project management and funding acquisition. M.d.W. was responsible for the conceptualisation, critically reviewing the writing, student supervision and project leadership.

\section{References}

1. Alley WM, Alley R. High and dry. Meeting the challenges of the world's growing dependence on groundwater. New Haven, CT: Yale University Press; 2017.

2. United Nations Economic Commission for Africa (ECA). The Africa water vision for 2025: Equitable and sustainable use of water for socioeconomic development. Addis Ababa: ECA; 2004.

3. Braune $E, X u Y$. A South African perspective on the protection of groundwater resources. In: Xu Y, Usher B, editors. Groundwater pollution in Africa. London: CRC Press; 2006. https://doi.org/10.1201/9780203963548.ch29

4. South African Department of Water Affairs (DWA). National water resource strategy. Pretoria: DWA; 2004.

5. South African Department of Water Affairs (DWA). Groundwater strategy 2010. Pretoria: DWA; 2010

6. Woodford A, Rosewarne P, Girman J. How much groundwater does South Africa have? Pretoria: SRK Consulting; 2006. Unpublished report.

7. Cobbing JE, Eales K, Gibson J, Lenkoe K, Cobbing BL. Operation and maintenance $(0 \& M)$ and the perceived unreliability of domestic groundwater supplies in South Africa. S Afr J Geol. 2015;118(1):17-32. https://doi. org/10.2113/gssajg.118.1.17

8. Pietersen K, Beekman HE, Holland M. South African groundwater governance case study. Report prepared for the World Bank in partnership with the South African Department of Water Affairs and the Water Research Commission. WRC report no. KV 273/11. Pretoria: Water Research Commission; 2011.

9. Knuppe K. The challenges facing sustainable and adaptive groundwater management in South Africa. Water SA. 2011;37(1):67-79. https://doi. org/10.4314/wsa.v37i1.64110

10. Barnard HC. An explanation of the $1: 500000$ General Hydrogeological Map Johannesburg 2526. Pretoria: Department of Water Affairs and Forestry; 2000.

11. Vegter JR. Groundwater development in South Africa and an introduction to the hydrogeology of groundwater regions. WRC report no. TT134/00. Pretoria: Water Research Commission; 2001.

12. Meyer R. Hydrogeology of Groundwater Region 10: The Karst Belt. Water Research Commission report no. TT 553/12. Pretoria: Water Research Commission; 2012

13. Stephens A, Bredenkamp DB. Institutional arrangements for groundwater management in dolomitic terrains: Situation analysis. WRC report no. KV140/02. Pretoria: Water Research Commission; 2002. 
14. Holland M, Wiegmans F. Geohydrology guideline development: Activity $18 \& 19$ desktop development of a dolomite hydrogeological compartment map and explanation booklet (report). Report prepared for the Department of Water Affairs by Water Geosciences Consulting as part of DWA project number 14/14/5/2: Implementation of dolomite guideline. Pretoria: Department of Water Affairs; 2009.

15. Cobbing JE. An updated water balance for the Grootfontein aquifer near Mahikeng. Water SA. 2018;44(1):54-64.

16. South African Department of Water and Sanitation (DWS). Third quarter performance evaluation report for Greater Mafikeng Bulk Water Supply Scheme. Period 1 October to 31 December 2014. Pretoria: Chief Directorate: Bulk Infrastructure Programme, Department of Water and Sanitation; 2014.

17. Cobbing JE. The Grootfontein aquifer as a hydro-social system [PhD thesis]. Port Elizabeth: Nelson Mandela Metropolitan University; 2017.

18. Bredenkamp DB. Verslag van hidrologiese opname in die Bo-Molopo Ondergrondse Waterbeheergebied [Report of hydrological surveys in the Upper Molopo Subterranean Water Control Area]. Report no. GH 1283. Pretoria: Department of Water and Sanitation; 1964. Afrikaans.

19. Temperley BN. Groundwater conditions on Spring Valley Farm, Rooigrond near Mafikeng. Report no. GH 1273. Pretoria: Department of Water and Sanitation, Pretoria; 1965.

20. Van Tonder GH, Janse van Rensburg H, Botha JF, Bredenkamp DB. Die modellering van grondwatervlakke in die Grootfonteinkompartement in Wes-Transvaal [The modelling of groundwater levels in the Grootfontein compartment in the Western Transvaal]. Water SA. 1986;12(3):151-160. Afrikaans.

21. Yin RK. Case study research. Design and methods. 4th ed. Los Angeles, CA: Sage Publications; 2009.

22. De Wit MJ, Booth P. Iphakade is Earth Stewardship Science. S Afr J Geol. 2016;119(1):3-14. https://doi.org/10.2113/gssajg.119.1.3

23. RSA. Act No. 36 of 1998: National Water Act. Cape Town: Republic of South Africa Government Gazette 398 (19182); 1998.

24. Lazarus P. Towards a regulatory framework for the management of groundwater in South Africa. Water Research Commission report no. 789/1/98. Pretoria: Water Research Commission; 1998.

25. South African Department of Water and Sanitation (DWS). National Water Policy Review (NWPR). Approved water policy positions, 31 January 2014. Pretoria: DWS; 2014.

26. Ngaka Modiri Molema District Municipality (NMMDM). Ngaka Modiri Molema District Municipality Annual Report for the 2014/2015 Financial Year. Mahikeng: NMMDM; 2015.

27. Annual report of Sedibeng Water Board for the 2014/15 financial year. Mahikeng: Sedibeng Water Board; 2015.

28. Seward $P$. Rethinking groundwater governance in South Africa [PhD thesis]. Cape Town: University of the Western Cape; 2015.

29. Ostrom E. Understanding institutional diversity. Princeton, NJ: Princeton University Press; 2005.

30. Hardin G. The tragedy of the commons. Science. 1968;162(3859):12431248. https://doi.org/10.1126/science.162.3859.1243
31. Nasar S. A Beautiful Mind. The life of mathematical genius and Nobel laureate John Nash. New York: Simon and Schuster; 1998.

32. Nash JF. Equilibrium points in n-person games. Proc Natl Acad Sci USA. 1950;36(1):48-49. https://doi.org/10.1073/pnas.36.1.48

33. Riemann K, Rust J, Hoosain M, Jack S. Water governance framework and action plan for conjunctive use. Draft final deliverable of WRC project K5/2332: Water governance of groundwater and surface water resources in South Africa. Pretoria: Water Research Commission; 2016.

34. Mukherji A, Shah T. Groundwater socio-ecology and governance: A review of institutions and policies in selected countries. Hydrogeol J. 2005;13:328345. https://doi.org/10.1007/s10040-005-0434-9

35. Manghee S, Poole A. Approaches to conducting political economy analysis in the urban water sector. World Bank Water Paper 74742. Washington DC: World Bank Group; 2012.

36. Seward P, Xu Y, Brendonck L. 2006 Sustainable groundwater use, the capture principle, and adaptive management. Water SA. 2006;4:473-482.

37. Folke C. Resilience: The emergence of a perspective for social-ecological systems analyses. Glob Environ Change. 2006;16:253-267. https://doi. org/10.1016/j.gloenvcha.2006.04.002

38. Burns M, Audouin M, Weaver A. Advancing sustainability science in South Africa. S Afr J Sci. 2006;102:379-384.

39. Mol APJ. Ecological modernization and the global economy. Glob Environ Politics. 2002;2(2):92-115. https://doi.org/10.1162/15263800260047844

40. Helbing D. Globally networked risks and how to respond. Nature. 2013;497:51-59. https://doi.org/10.1038/nature12047

41. Perrow C. Normal accidents: Living with high-risk technologies. Princeton, NJ: Princeton University Press; 1999.

42. Vegter JR. Verslag oor grondwaterondersoek Lichtenburg [Report of a groundwater investigation]. Report no. GH 1116. Pretoria: Department of Water and Sanitation; 1960. Afrikaans.

43. Vahrmeijer JT, Annandale JG, Bristow KL, Steyn JM, Holland M. Drought as a catalyst for change: A case study of the Steenkoppies Dolomite Compartment. In: Schwabe K, Albiac-Murill, J, Connor JD, Hassan R, Meza González L, editors. Drought in arid and semi-arid regions. Dordrecht: Springer; 2013. https://doi.org/10.1007/978-94-007-6636-5_14

44. Holland M. Geohydrology guideline development: Activity 25: Geohydrological assessment of the Steenkoppies Dolomite Compartment. Report prepared for the Department of Water Affairs by Water Geosciences Consulting as part of DWA project number 14/14/5/2: Implementation of dolomite guideline. Pretoria: Department of Water Affairs; 2009.

45. RSA. National development plan 2030 - Our future - Make it work. Pretoria: National Planning Commission; 2012.

46. Aarnoudse $E$, Bluemling B, Wester $P, Q u$ W. The role of collective groundwater institutions in the implementation of direct groundwater regulation measures in Minqin County, China. Hydrogeol J. 2012;20:1213-1221. https://doi. org/10.1007/s10040-012-0873-z

47. Stockholm Resilience Centre. Governance of social-ecological systems in an increasingly uncertain world needs to be collaborative, flexible and learningbased. Stockholm Resilience Centre Research Insight No. 3: Adaptive governance. Stockholm: Stockholm University; 2012. 